\title{
DISCUSSION
}

\section{Discussion on chemostratigraphy of predominantly siliciclastic Neoproterozoic successions: a case study of the Pocatello Formation and Lower Brigham Group, Idaho, USA}

G. Shields comments: Correlation of Precambrian sedimentary suites is a difficult task at best. The lack of fossil assemblages and poor direct dating resolution mean that other methods must be found to supplement the pure lithostratigraphic approach. Since the pioneering work of Veizer et al. (1983), isotope stratigraphy has proven to be a highly useful correlation tool for the Precambrian and Cambrian (Kaufman, Knoll \& Awramik, 1992; Wickham \& Peters, 1993; Derry, Kaufman \& Jacobsen, 1992). However, care must be taken in both the selection of the samples and the interpretation of results.

Loren Smith, Alan Kaufman, Andrew Knoll and Paul Karl Link (1994) argue, on the basis of 'best preserved' or 'least altered' strontium and carbon isotope ratios in bulk carbonate, that the sediments of the Pocatello Formation and Lower Brigham Group of Idaho, USA, were deposited between the Sturtian and Varanger glacial episodes (possibly about $<780$ and $600 \mathrm{Ma}$ respectively). The now metamorphosed sediments sit directly on top of glaciogenic deposits which they consider, by inference, to be of Sturtian age. Such an interpretation does not in itself seem unlikely, although I would maintain, as devil's advocate, that the geochemical data presented by Smith $e t$ al. make such a proposition less, rather than more likely.

First, Smith et al. find that carbonate $\delta^{13} \mathrm{C}$ values rise up-section from about $-6 \%$ up to $+8.8 \%$ (PDB), mirroring similar trends that have been found in several sections worldwide for the periods directly following the Sturtian and Varanger glaciations. Smith et al. maintain that the high $\delta^{13} \mathrm{C}$ carbonate values of up to $+8.8 \%$ are unique to post-Sturtian/pre-Varanger time in the Neoproterozoic. Absolute values are often misleading. The highest post-Varanger $\delta^{13} \mathrm{C}$ value cited by the authors is $+7 \%$ o (e.g. Derry, Kaufman \& Jacobsen, 1992, and others). The difference between this and $+8.8 \%$ is possibly insignificant, being dependent upon local conditions of deposition and/or subsequent alteration. Other, very high $\delta^{13} \mathrm{C}$ values from post-Varanger carbonates, are in fact known but not cited. Knoll et al. (1986) report $+10 \%$ from the Dracoisen Formation of the Polarisbreen Group, Spitsbergen and $+14 \%$ from Nordaustlandet. In both these sections $\delta^{13} \mathrm{C}$ appears to have risen from negative values directly after the upper Varangerian glaciation. Fairchild \& Spiro (1987) report further data from Spitsbergen which show a trend from $\approx-4 \%$ o through $+3 \%$ and $+5 \%$ to $\approx+10 / 11 \%$. This is similar to the trend reported by Smith et al.

Second, Smith et al. (1994) find that their 'least disturbed' sample gives a ${ }^{87} \mathrm{Sr} /{ }^{86} \mathrm{Sr}$ ratio of 0.70766 . This would present a maximum value for coeval seawater. Derry, Kaufman \& Jacobsen (1992) demonstrated that seawater ${ }^{87} \mathrm{Sr} /{ }^{86} \mathrm{Sr}$ may have been at least as low as 0.7062 just after the Sturtian ice age, perhaps rising to a maximum of $0.7068-0.7070$. Thus, diagenetically altered, bulk carbonate ${ }^{87} \mathrm{Sr} /{ }^{86} \mathrm{~S}$ ratios are most likely to be higher than about $0.7062-0.7068$ for post-Sturtian rocks. Kaufman, Jacobson \& Knoll (1993) constrained a second sharp climb in seawater ${ }^{87} \mathrm{Sr} /{ }^{86} \mathrm{Sr}$ from about 0.7066 before, up to at least 0.7080 sometime after, the Varanger glaciation. The value of 0.7076 of Smith $e t$ al. is therefore consistent with both a postSturtian and a post-Varanger age.

Smith et al. summarize all reliable, post-Sturtian data as 0.7070 to 0.7076 and post-Varanger data s 0.7080 to 0.7085 , but this ignores the fact that seawater ${ }^{87} \mathrm{Sr} /{ }^{86} \mathrm{Sr}$ must have risen from $<0.7070$ up to $\approx 0.7080$ sometime during early Vendian time. Sample 08LHS92, the 'second best' sample of Smith et al., shows little sign of $\mathrm{Sr}$ diagenetic exchange. It contains over $2000 \mathrm{ppm} \mathrm{Sr}$, has a $\mathrm{Mn} / \mathrm{Sr}$ ratio of 0.01 and the least depleted $\delta^{18} \mathrm{O}$ value of any sample from this general locality. Therefore, one would expect a ${ }^{87} \mathrm{Sr} /{ }^{86} \mathrm{Sr}$ ratio at least close to our best approximation of seawater ${ }^{87} \mathrm{Sr} /{ }^{86} \mathrm{Sr}$ for this time. 0.70798 is far higher than the range of post-Sturtian ratios displayed in Table 2 of Smith $e t a l$. and lies within the expected range of values for a post-Varanger scenario. The two 'best' samples appear to be either significantly altered post-Sturtian or slightly altered postVaranger samples. Considering the favourable nature of the other geochemical parameters, the latter possibility seems more likely.

Third, the authors ${ }^{87} \mathrm{Sr} /{ }^{86} \mathrm{Sr}$ data show a positive correlation with depletion in ${ }^{18} \mathrm{O}$, possibly indicating that some radiogenic $\mathrm{Sr}$ was introduced into the system during metamorphism and/or diagenesis. Using this as an indicator of diagenetic exchange of strontium, the authors maintain that the 'most diagenetically disturbed' sample (lowest $\delta^{18} \mathrm{O}$ value) gives ${ }^{87} \mathrm{Sr} /{ }^{86} \mathrm{Sr}=0.70885$. That it has a high $\mathrm{Sr}$ isotope ratio, and is therefore confirmed as the 'most disturbed' sample by Smith et al., is hardly surprising as this is stratigraphically the uppermost sample, and seawater ${ }^{87} \mathrm{Sr} /{ }^{86} \mathrm{Sr}$ is considered to have increased markedly after both ice ages. An approach where data are brought together for the assessment of post-depositional exchange over a period where there appears to have been such rapid and significant changes in original seawater Sr-, C- and O-isotope ratios (Derry et al. 1992), cannot be valid. This is not to mention the fact that only five samples were considered over almost $2000 \mathrm{~m}$ of section from various localities and are therefore unlikely to have suffered the same post-depositional alteration histories.

A comparable chemostratigraphy 'test case' paper (Kaufman, Knoll \& Awramik, 1992) came to the conclusion that the Upper Tindir Group, northwest Canada, which also sits on a glaciogenic deposit, was of post-Sturtian/pre-Varanger age on the basis of a clearly altered, but 'best preserved', $\delta^{13} \mathrm{C}$ excursion of $+4.7 \%$ and ${ }^{87} \mathrm{Sr} /{ }^{86} \mathrm{Sr}$ of 0.7065 . This is indeed a pre-Varanger signature due to the much lower Sr-isotope ratio, which itself probably represents a slightly altered maximum value for this time.

Another study (Peters, Wickham \& Miller, 1992; Wickham \& Peters, 1993) which investigated the correlative McCoy Creek Group in Nevada and Utah reported $\delta^{13} \mathrm{C}$ excursions from -2.4 up to $+11.6 \%$ and -2.1 to $+9.9 \%$, as well as ${ }^{87} \mathrm{Sr} /{ }^{86} \mathrm{Sr}$ ratios of between 0.707 and 0.708 . Their conclusion, after comparison with published Sr-isotope work (Asmerom et al. 1991), was that these rocks were deposited between 600 and $540 \mathrm{Ma}$, i.e. postVarangerian. This contradicts the conclusions of Smith et al.

In their conclusions section, Smith et al. state '... when $\mathrm{Sr}$ isotopic ratios fall in the range of 0.7075 to 0.7085 , differentiation between an unaltered $570 \mathrm{Ma}$ old limestone and a moderately altered $700 \mathrm{Ma}$ old sample can be impossible in the absence of additional data'. As the above is true for the samples concerned and there is no additional data, I see no reason for plumping for a post-Sturtian age as the authors do. On the basis 
of carbonate chemostratigraphy alone, the case of the Pocatello Formation remains 'unproven', but I would argue that the weight of geochemical evidence lies in favour of a post Varanger age.

L. H. Smith, A. J. Kaufman, A. H. Knoll \& P. K. Link reply: We endorse Shields' statement that isotopic chemostratigraphy has much to offer in the correlation of Neoproterozoic sedimentary successions and can hardly fault his contention that, in such studies, samples must be carefully selected and evaluated. Most of our chemostratigraphic research has been aimed at establishing major trends in the secular variation of $\mathrm{C}$ - and $\mathrm{Sr}$-isotopic signatures through Neoproterozoic time, concentrating on thick, little-altered, carbonate-rich, and fossiliferous successions from Svalbard (Knoll et al. 1986; Derry et al. 1989), Namibia (Kaufman et al. 1991; Grotzinger et al. 1995), northwestern Canada (Narbonne, Kaufman \& Knoll, 1994; Asmerom et al. 1991; Kaufman, Knoll \& Narbonne, unpub. data), and Siberia (Knoll et al. 1995; Pelechaty, Kaufman \& Grotzinger, in press; Kaufman et al. in press). For all of these basins, chronostratigraphic data are known from multiple sections collected along and across basin axes.

The paper on which Shields comments asks a very different question: can useful chronostratigraphic data be preserved in the many Neoproterozoic sections that are not thick, littlealtered, carbonate-rich and fossiliferous? We are pleased that Shields accepts the conclusion that the C-isotopic composition of carbonates can be preserved in a little-altered state despite metamorphism (see also Kaufman et al. 1991; Wickham \& Peters, 1993), but we are less optimistic than he that unaltered Sr-isotopic signatures have survived in our Idaho samples.

In light of Shields' comment, it is important to re-emphasize that our geochemical results fit into a lithostratigraphic and sequence stratigraphic framework based on years of careful field research (e.g. Link et al. 1993). We did not evaluate our chemostratigraphic data in a geological vacuum, and it would be hazardous to do so. None the less, our principal isotopic basis for concluding that uppermost Pocatello and lower Brigham rocks represent post-Sturtian rather than post-Varanger sedimentation is the magnitude of the post-glacial peak in $\delta^{13} \mathrm{C}$. We reiterate that in carbonates of unambiguous stratigraphic position and marine origin, $\delta^{13} \mathrm{C}$ values of $+8.8 \%$ or higher are known from many post-Sturtian but no post-Varanger rocks. In disputing this observation, Shields cites data from postVaranger carbonates in Svalbard that show $\delta^{13} \mathrm{C}$ values of $>$ $+10 \%$. Having completed many of the quoted analyses ourselves, we are, of course, aware of their existence; however, we are also aware that the marine origin of these rocks is in considerable doubt. According to Fairchild \& Hambrey (1984), the dolostones in question contain a suite of sedimentological characters 'commonly found in sequences interpreted as lacustrine in origin'. Harland, Hambrey \& Waddams (1993) similarly observed that these carbonates contain features 'commonly associated with lakes which periodically dry out.' Neither Fairchild \& Hambrey (1984) nor Harland, Hambrey \& Waddams (1993) ruled out a marginal marine depositional setting, but in the most recent discussion of these rocks, Fairchild \& Hambrey (1995) explicitly interpreted them as playa lake deposits. Based on these interpretations and our own field and laboratory experience with these carbonates, we are extremely wary of attempts to use them in reconstructing the Neoproterozoic history of seawater.

Shields further asserts that the difference in magnitude between $+7 \%$ - the highest known $\delta^{13} \mathrm{C}$ values for postVaranger Neoproterozoic carbonates - and the $+8.8 \%$ values recorded in Caddy Canyon limestones may not be significant.
Perhaps, but in evaluating this contention, one must bear in mind that the $+7 \%$ value quoted is not a mean value for postVaranger carbonate maxima; it represents the highest values recorded in immediately post-Varanger sections from five continents (Kaufman \& Knoll, 1995). In comparison, the $+8.8 \%$ value from the Caddy Canyon limestone represents a minimum value for the post-glacial positive excursion in Idaho; we have no assurance that sparse Caddy Canyon carbonates actually capture the true post-glacial peak. In the Mackenzie Mountains of northwestern Canada, carbonate-rich sections record another part of the same basin sampled in Idaho. Both post-Sturtian and post-Varanger $\mathrm{C}$-isotopic profiles are known, but only the postSturtian maximum $(+10.6 \%)$ matches or exceeds that measured in Caddy Canyon limestone. The post-Varanger peak in the Mackenzie sections sampled is $+5.9 \%$ (Narbonne, Kaufman \& Knoll, 1994).

Shields heroically interprets the ${ }^{87} \mathrm{Sr} /{ }^{86} \mathrm{Sr}$ values we reported as depositional, but given the strong alteration of $\mathrm{O}$-isotopic ratios in measured samples, we believe that this exercise is doomed to failure. The $\delta^{18} \mathrm{O}$ values for Idaho samples are all $-13.4 \%$ or lower; seawater $\mathrm{Sr}$-isotopic values are unlikely to survive diagenetic alteration that depletes ${ }^{18} \mathrm{O}$ so dramatically. As shown in our paper, a plot of $\delta^{18} \mathrm{O}$ vs. ${ }^{87} \mathrm{Sr} /{ }^{86} \mathrm{Sr}$ for Idaho samples yields a straight line with $r^{2}=0.9$. The line can be defined by samples from a single horizon (Blackrock Canyon Limestone), but both stratigraphically lower (uppermost Pocatello) and younger (Caddy Canyon) samples plot along the same trend. Shields correctly notes that if seawater ${ }^{87} \mathrm{Sr}{ }^{86} \mathrm{Sr}$ varied significantly through the time interval under study, a single cross-plot vs. $\delta^{18} \mathrm{O}$ for all samples may obscure rather than facilitate evaluation; however, the reverse is equally true. If ${ }^{87} \mathrm{Sr} /{ }^{86} \mathrm{Sr}$ covaries closely with O-isotopic evidence for diagenetic alteration, the prospects for recognizing seawater ${ }^{87} \mathrm{Sr} /{ }^{86} \mathrm{Sr}$ in samples highly depleted in ${ }^{18} \mathrm{O}$ are dim. Our contention is that pervasive alteration obviates inferences about seawater ${ }^{87} \mathrm{Sr} /{ }^{86} \mathrm{Sr}$ variation in this succession.

We believe that the only statement about strontium that can be made with confidence is that seawater ${ }^{87} \mathrm{Sr} /{ }^{86} \mathrm{Sr}$ at the time of deposition of the post-glacial Blackrock Canyon Limestone was less than 0.7076 and may have been considerably lower. In Shields' view, this datum is consistent with either post-Sturtian or post-Varanger deposition, citing our report of a 0.7072 value for limestones of the Tepee Formation that cap Varanger Ice Brook tillites in northwestern Canada (Kaufman, Jacobsen \& Knoll, 1993). New data (Kaufman, Knoll \& Narbonne, unpub. data) now suggest, however, that the Ice Brook tillite correlates only with lower Varanger glaciogenic rocks elsewhere and that upper Varanger glaciation postdates the Tepee Formation. If correct, this correlation leaves us without a single example of truly post-Varanger Proterozoic carbonate with ${ }^{87} \mathrm{Sr} /{ }^{86} \mathrm{Sr}<c$. 0.7080 .

What, then, are the reasonable constraints on correlation of the Pocatello Formation and lower Brigham Group? In light of the latest available information, Shield's interpretation of the $\mathrm{Sr}$-isotopic data and our interpretation of the $\mathrm{C}$-isotopic data are both inconsistent with post-Varanger sedimentation. Our respective interpretations of the isotopic data do not, in and of themselves, preclude an interglacial Varanger age for the succession, but the fact that uppermost Pocatello and lower Brigham strata lie above the younger of two Pocatello glacial pulses (Crittenden, Christie-Blick \& Link, 1983) makes this correlation unlikely. Further, such a correlation would require the deposition of more than $2000 \mathrm{~m}$ of shallow marine and braided fluvial strata between stades of Varanger glaciation; in fact, these strata contain several orders of depositional sequence and sequence boundaries, including one interpreted as the 
eustatic signature of Varanger glaciation (Levy, Christie-Blick \& Link, 1994). We are left with a post-Sturtian interpretation as the only one that fits both isotopic and lithostratigraphic data.

The chemostratigraphic correlation of Neoproterozoic rocks is a youthful endeavour, and it is likely that isotopic signatures outside our present experience will be documented. We do not dispute the abstract notion that there may be more to Heaven and Earth than is dreamt of in our philosophy (or data sets). None the less, we believe that, on balance, available isotopic data favour the Sturtian age for Pocatello glaciation earlier inferred from regional sequence stratigraphy (Christie-Blick \& Levy, 1989) and not the Varanger age plumped for (nice phrase) by Shields.

\section{References}

Asmerom, Y., Jacobsen, S. B., KNoll, A. H., Butterfield, N. B. \& SwETT, K. 1991. Strontium isotopic variations of Neoproterozoic seawater: implications for crustal evolution. Geochimica et Cosmochimica Acta 55, 2883-94.

Christie-Blick, N. \& Levy, M., Eds. 1989. Late Proterozoic and Cambrian tectonics, sedimentation and record of early metazoan evolution in the western United States. Field Trip Guidebook T331, 28th International Geological Congress, Washington, D.C., American Geophysical Union.

Crittenden, M. D., Christie-Blick, N. \& Link, P. K. 1983. Evidence for two pulses of glaciation during the late Proterozoic in northern Utah and southeastern Idaho. Bulletin, Geological Society of America 94, 437-50.

DeRrY, L. A., Keto, L. S., JacobSen, S. B., KNOLL, A. H. \& SWETT, K. 1989. Sr isotopic variations in Upper Proterozoic carbonates from Svalbard and East Greenland. Geochimica et Cosmochimica Acta 53, 2331-9.

Derry, L. A., Kaufman, A. J. \& Jacobsen, S. J. 1992. Sedimentary cycling and environmental change in the late Proterozoic: Evidence from stable and radiogenic isotopes. Geochimica et Cosmochimica Acta 56, 1317-29.

FatrChild, I. J. \& Spiro, B. 1987. Petrological and isotopic implications of some contrasting Late Precambrian carbonates, NE Spitsbergen. Sedimentology 34, 973-89.

FAIRCHILD, I. J. \& HamBreY, M. J. 1984. The Vendian succession of northeastern Spitsbergen: petrogenesis of a dolomite-tillite association. Precambrian Research 26, $111-67$.

FaIRCHILD, I. J. \& HAMBREY, M. J. 1995. Vendian basin evolution in East Greenland and NE Svalbard. Precambrian Research 73, 217-33.

Grotzinger, J. P., Bowring, S. A., SAYLoR, B. Z. \& KaUfman, A. J. 1995. New biostratigraphic and geochronologic constraints on early animal evolution. Science 270, 598-604.

Harland, W. B., Hambrey, M. J. \& Waddams, P. 1993. Vendian geology of Svalbard. Norskpolarinstitut Skrifter $193,1-150$

KaUfMan, A. J. \& KNOLL, A. H. 1995. Neoproterozoic variations in the carbon isotopic composition of seawater: Stratigraphic and biogeochemical implications. Precambrian Research 73, $27-49$.

Kaufman, A. J., Hayes, J. M., KnOll, A. H. \& Germs, G. J. B. 1991. Isotopic compositions of carbonates and organic matter from upper Proterozoic successions in Namibia: stratigraphic variation and the effects of diagenesis and metamorphism. Precambrian Research 49, 301-27.

Kaufman, A. J., Jacobsen, S. B. \& KNOLl, A. H. 1993. The Vendian record of $\mathrm{Sr}$ - and $\mathrm{C}$-isotopic variations in seawater: Implications for tectonics and paleoclimate. Earth and Planetary Science Letters 120, 409-30.
KaUfman, A. J., Knoll, A. H., Grotzinger, J. P., Semikhatov, M. A., JACOBSEN, S. B. \& AdAMS, W. 1996. Integrated chronostratigraphy of Proterozoic-Cambrian boundary beds, Western Anabar Uplift, Siberia. Geological Magazine in press.

KAUfMaN, A. J., KNOLl, A. H. \& AWramiK, S. M. 1992 Biostratigraphic and chemostratigraphic correlation of NeOproterozoic sedimentary successions: Upper Tindir Group, northwestern Canada, as a test case. Geology 20, 181-85.

Knoll, A. H., Hayes, J. M., Kaufman, A. J., Swett, K. \& LAMBERT, I. B. 1986. Secular variation in carbon isotope ratios from upper Proterozoic successions of Svalbard and East greenland. Nature 321, 832-8.

Knoll, A. H., Grotzinger, J. P., Kaufman, A. J. \& Kolosov, P. 1995. Integrated approaches to terminal Proterozoic stratigraphy: An example from the Olenek Uplift, northeastern Siberia. Precambrian Research 79, 251-70.

Levy, M., Christie-Blick, N. \& LinK, P. K. 1994. Neoproterozoic incised valleys of the eastern Great Basin, Utah and Idaho: fluvial response to changes in depositional base-level. SEPM Special Paper 51, 369-82.

Link, P. K., Christie-Blick, N., Devlin, W. J., Elston, D. P., Horodyski, R. J., Levy, M., Miller, J. M. G., Pearson, R. C., Prave, A., Stewart, J. H., Winston, D., Wright, L. A. \& Wrucke, C. T. 1993. Middle and late Proterozoic stratified rocks of the western U.S. Cordillera, Colorado Plateau, and Basin and Range Province. In The Geology of North America, Vol. C-2 (eds J. C. Reed, M. E. Bickford, R. S. Houston, P. K. Link, D. W. Rankin, P. K. Sims \& W. R. Van Schmus), pp. 463-595. Boulder, Colorado: Geological Society of America.

NARBONNE, G. M., KaufMan, A. J. \& KNOLl, A. H. 1994. Integrated chemostratigraphy and biostratigraphy of the upper Windermere Supergroup (Neoproterozoic), Mackenzie Mountains, northwestern Canada. Bulletin, Geological Society of America 106, 1281-92.

Pelechaty, S., Kaufman, A. J. \& Grotzinger, J. P. 1996. Evaluation of $\delta^{13} \mathrm{C}$ chemostratigraphy for interbasinal correlations: Vendian strata of the Olenek Uplift and Kharaulakh Mountains, Siberian Platform, Russia. Bulletin, Geological Society of America, in press.

Peters, M. T., Wickham, S. M. \& Miller, D. M. 1992. High $\delta^{13} \mathrm{C}$ Late Proterozoic carbonates of the North American cordillera. GSA Abstracts with programs A114.

WiCkHAM, S. M. \& PETERs, M. T. 1993. High $\delta^{13}$ C Neoproterozoic carbonate rocks in western North America. Geology 21, $165-8$.

Smith, L. H., Kaufman, A. J., Knoll, A. H. \& Link, P-K. 1994. Chemostratigraphy of predominantly siloclastic Neoproterozoic successions: a case study of the Pocatello Formation and Lower Brigham Group, Idaho, USA. Geological Magazine 131, 301-14.

Veizer, J., Compston, W., Clauer, N. \& Schidlowski, M. 1983. ${ }^{87} \mathrm{Sr} /{ }^{86} \mathrm{Sr}$ in late Proterozoic carbonates: evidence for a "mantle" event at $=900 \mathrm{Ma}$ ago. Geochimica et Cosmochimica Acta 47, 295-302.

SHIELDS, G. Institute of Geology, Sonneggstrasse 5, ETHZentrum, CH-8092 Zurich, Switzerland

SMITH, L. H. Department of Biological Sciences, University of Southern California, Los Angeles, CA 90089, USA

KaufMan, A. J. \& KNoll, A. H., Botanical Museum, Harvard University, Cambridge, MA 02138, USA

LiNK, P. K. Department of Geology, Idaho State University, Pocatello, ID 83209, USA 